\title{
Vitellogenin of the solitary bees Centris tarsata and Centris analis (Hymenoptera: Apidae): cDNA structural analysis and gene expression
}

\author{
Júlia Colombelli AgostinI ${ }^{1,2}$, Claudineia Pereira Costa $^{3}$, Jaíne Taís FerreirA ${ }^{1}$, \\ Adriana Cristina Dias ${ }^{1}$, Nathália Prestes Guerra ${ }^{1}$, Zilá Luz Paulino SimÕes ${ }^{4}$, \\ Anete Pedro LOURENÇO ${ }^{1}$

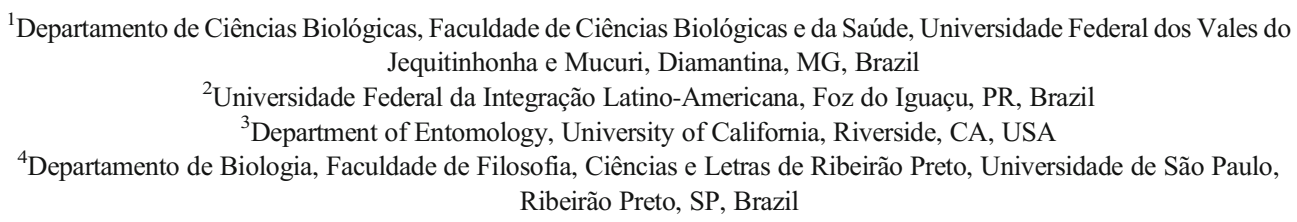

Received 24 April 2020 - Revised 4 September 2020 - Accepted 29 September 2020

\begin{abstract}
Vitellogenin (Vg) plays a vital role in the reproduction of oviparous species, as the precursor of the major egg storage protein. In bees, most of the studies of this protein rely on honey bees (Apis mellifera), and very little is known in solitary species. The solitary bees Centris tarsata and C. analis were chosen to characterize $v g$ cDNA and better understand its expression. The Vg-deduced amino acid sequences from these bees have typical Vg features found in other hymenopterans. Besides its main site of synthesis, the fat body, transcripts of $v g$ were also observed in ovaries. Males also showed expression of $v g$, although in lower levels compared with females. During development, $v g$ expression was observed in late larvae, pupae, and female adults. The highest amounts of $v g$ transcripts were observed in egg-laying females. Expression of $v g$ increased rapidly in a few hours after female adult emergence, which indicates that its gene expression does not depend on mating to be triggered.
\end{abstract}

vitellogenin / gene expression / males / ovaries

\section{INTRODUCTION}

Vitellogenin $(\mathrm{Vg})$ is one of the most important reproduction-related proteins in egg-laying animals, as it is the precursor of the yolk protein vitellin (Vn), the main energy source for develop-

Electronic supplementary material The online version of this article (https://doi.org/10.1007/s13592-020-00818-6) contains supplementary material, which is available to authorized users.

Corresponding author: A. Lourenço, anete.lourenco@ufvjm.edu.br Manuscript editor: Cedric Alaux ing embryos (Raikhel and Dhadialla 1992; Sappington and Raikhel 1998). Thus, vitellogenesis is crucial for the reproduction of oviparous animals (Wahli 1988; Carducci et al. 2019). In several species of insects, including social and solitary bees, the ability to initiate vitellogenesis and subsequently promote the growth of the ovaries depends on rates of synthesis of $\mathrm{Vg}$ (Hartfelder and Engels 1998; Barchuk et al. 2002; Morandin et al. 2019). Vg is synthesized primarily by the fat body and after synthesis undergoes extensive structural alterations such as phosphorylation, lipidation, glycosylation, among other processes (Raikhel and Dhadialla 1992). It 
may undergo proteolytic processing, and is then transported by hemolymph, and finally endocytosed by specific receptors located on the surface of oocytes, where it is stored as Vn (Raikhel and Dhadialla 1992; Guidugli-Lazzarini et al. 2008; Tufail and Takeda 2008).

$\mathrm{Vg}$ is a high-density protein consisting of carbohydrates, a phosphate group, and residues of amino acids covalently bound to phospholipids and diacylglycerol, giving the structure of $\mathrm{Vg}$ the denomination of lipoprotein (Engels et al. 1990; Wheeler and Kawooya 1990). Studies on social insects have stated that this protein is multifunctional (Richards 2019). In addition to its role in reproduction, it participates in other functions, such as regulating longevity through its antioxidative properties (Seehuus et al. 2006), participating in the immune response by passing information from the queen to its offspring (Salmela et al. 2015; Harwood et al. 2019), and is involved in the energy metabolism of glial cells in the brain (Münch et al. 2015). Additionally, it assists in the transport of molecules, such as sugar, lipids, phosphates, vitamins, zinc, antioxidants, and hormones, which explains its appearance in males (Harnish and White 1982; Sappington and Raikhel 1998).

The complete sequencing of the cDNA of $v g$ and expression analyses have been carried out in few Hymenoptera species, and it is the most wellstudied in the social bee Apis mellifera (Piulachs et al. 2003) from the Apidae family. $v g$ expression in A. mellifera is dynamic and varies: both during and across developmental stages, and according to sex, hormones, and castes (Barchuk et al. 2002; Piulachs et al. 2003; Guidugli et al. 2005). Vg titers in the hemolymph and its transcripts are much higher in queens than in males and workers (Engels et al. 1990; Barchuk et al. 2002; Piulachs et al. 2003; Guidugli et al. 2005). Gene expression in queens begins when individuals are still in the larval stage, then disappears in the early stages of the pupae, and then reappears in the middle of the pupal stage (Piulachs et al. 2003; Guidugli et al. 2005). vg expression in workers and males similarly initiates during the larval stages (with strong expression during the fifth instar), which decreases gradually until it disappears during pupal development, to then reappear during the last pupal stage in workers and newly emerged males (Barchuk et al. 2002; Piulachs et al. 2003; Guidugli et al. 2005). Within insects, the fact that $\mathrm{Vg}$ has been implicated in many functions besides reproduction suggests that male and workers expression of $v g$ is related in some way to these other functions (Piulachs et al. 2003). However, the costly production of $\mathrm{Vg}$ in workers is also correlated to social behavior (Amdam et al. 2004a; Amdam and Page 2010).

The reproductive division of labor is a hallmark of eusociality, where individuals with differences in physiology, morphology, and behavior are separated into reproductive castes: queens, the reproductive females, and workers, the nonreproductive females (Sumner et al. 2018). It has been suggested that bee eusociality evolved through the developmental decoupling of reproductive and maternal behavior from the ancestral solitary bee reproductive "ground plan" (Amdam et al. 2004a). Vg is a key protein in this process because, in addition to reproduction, it is essential to the division of labor playing an important role in regulating the nurse-to-forager transition (Amdam and Omholt 2003). Therefore, studying solitary species may provide a basis for genetic, physiological, and behavioral underpinnings for evolutionary transitions to sociality. Despite the great knowledge of this protein in other species of insects, very little is known in solitary bees. There is only one study that characterizes $v g$ in a solitary bee: Osmia cornifrons, belonging to the Megachilidae family (Lee et al. 2015).

Centris (Hemisiella) tarsata Smith 1874 and Centris (Heterocentris) analis (Fabricius 1804) are solitary, oil-collecting bees with a broad geographic range that extends from central Mexico to southern Brazil (Moure et al. 2012). They belong to the Apinae subfamily (Apidae family), which comprises solitary (most of the species), primitively social (Bombini), and highly eusocial bees (Meliponini and Apini) (Bossert et al. 2019). Nonetheless, studies have mainly focused on social species, and only one solitary Apidae has had its genome sequenced, annotated, and published (Habropoda laboriosa; Kapheim et al. 2015).

Females of $C$. tarsata and $C$. analis build their nests in pre-existing cavities in deadwood, hollow plant steams, or abandoned nests (Michener 2007; 
Garófalo et al. 2012), allowing for trap-nests studies (Krombein 1967; Macivor 2017). They are economically significant in pollinator-dependent crops, and the best solitary species candidates for pollination programs in Brazil since they are widely distributed, relatively constant, and abundant in most cavity-nesting bee studies (Garófalo et al. 2004, 2012). In fact, trap-nests occupied by these species in the Neotropics are very common, and after the eggs are laid, immatures can be developed in the laboratory (Garófalo et al. 2004, 2012; Araújo et al. 2016; Lourenço et al. 2020). Molecular studies have indicated that Centris is the closest genus to the corbiculate bees (Euglossini, Meliponini, Bombini, and Apini), where eusociality evolved (Martins et al. 2014). As the sister clade of the corbiculate bees, Centris is one the best group for interpreting physiological and genomic evolution of Apinae (Martins et al. 2014). These features make these species potential model organisms for solitary bees from the Apidae family for studies on evolution, ecology, behavior, genetics, and physiology.

Here, we report the first molecular information on $\mathrm{Vg}$ from C. tarsata and C. analis. Expression studies were carried out throughout development, across tissues and sexes. The Vg encoding genes were sequenced and used for in silico and molecular characterization in these two species. These data were used to characterize Vg structure and expression within these two species as well as to perform cross-species comparisons to interpret our results within the social and solitary context. Centris provides a phylogenetically comparison to previous studies on $\mathrm{Vg}$ of the eusocial bees (e.g., A. mellifera and Bombus), in addition, to investigate reproductive physiology inherent to solitary bees independently to phylogenetic relatedness. The current work aims to bridge the gap on the lack of information between the reproduction-related proteins and reproduction physiology in solitary Apinae bees, essential to understanding the evolution of sociality within corbiculate bees. The objectives of this work were to (1) characterize Vg sequence and expression in C. tarsata and C. analis, (2) investigate similarities of $\mathrm{Vg}$ structure and expression in solitary and social bees, (3) determine whether males (sexes) and ovaries (tissues) express $v g$, and (4) determine whether age and mating influences on $v g$ expression profiles on adult females (in newly emerged bees and foundress).

\section{MATERIAL AND METHODS}

\subsection{Sample collection}

Nests of C. tarsata were collected in 20152017 from a trap-nest station located in the Juscelino Kubitschek (JK) Campus of the Federal University of the Jequitinhonha and Mucuri Valleys, Diamantina, Minas Gerais, Brazil. Nests of C. analis were collected in 2019 from trap-nests located in the Experimental Apiary area of the Faculdade de Medicina de Ribeirão Preto, Universidade de São Paulo, Ribeirão Preto, São Paulo, Brazil. The trap-nests were made of cardboard tubes or bamboo canes (description of the cardboard and bamboo canes for $C$. tarsata in Araújo et al. 2016; Lourenço et al. 2020; description of the cardboard tubes of $5.5 \mathrm{~cm}$ length for C. analis in Alonso et al. 2012). Using this methodology, about 10 nests/year is occupied by $C$. tarsata (Araújo et al. 2016; Lourenço et al. 2020) and 12 nests/year by $C$. analis (Alonso et al. 2012) in the same areas we sampled, and the number can vary depending on the year. The number of individuals per nest ranged from 2 to 5 for C. tarsata, and from 2 to 3 for C. analis (Figure S1).

For both bee species, the occupied nests were opened and immatures were individually placed in a 48-cell culture plate, then left in an incubator at $28{ }^{\circ} \mathrm{C}$ to develop until the required stages: feeding larvae (weighing $0.060 \pm 0.026 \mathrm{~g}$ ), spinning larvae (non-feeding larvae; weighing 0.171 $\pm 0.033 \mathrm{~g}$ ), white-eyed pupae (white eye and unpigmented cuticle), brown-eyed pupae (brown eye and unpigmented cuticle), newly emerged female, and newly emerged male (description of the methodology in Figure S1). As in all solitary bee species, the egg is placed on top of a food mass, and then the foundress closes the cell (Batra 1984). Thus, during transference, the feeding larvae were transferred with the food. Bees were considered newly emerged when they were moving, their wings were completely expanded and dark, and the eyes were green. In four nests, we 
also compared the gene expression of two newly emerged females of $C$. tarsata from each nest. The bees were collected at the same time, and thus with few hours of difference in development, which we called older (egg-laid earlier; emerge later) and younger bees (Figure S1). Foundress (egg-laying) females of unknown age were also captured when either returning from the field to their nest or vice versa. The ovaries of foundresses were dissected out in cold DEPC-treated saline $(0.9 \% \mathrm{NaCl})$, alongside the abdominal carcass carrying fat body cells and cuticular epithelial cells. All samples were kept at $-80{ }^{\circ} \mathrm{C}$ until total RNA extractions.

\subsection{Identification of the vitellogenin gene in Centris tarsata}

The $v g$ partial cDNA sequence of $C$. analis was provided by MMG Bitondi and $\mathrm{T}$ Falcon from the raw sequences of RNA-Seq libraries (GenBank BioProject ID PRJNA490324; Falcon et al. 2019). This sequence was deposited in GenBank (GenBank Accession no. BK013350), and used to design several primers for sequencing the C. tarsata $v g$ cDNA (Table S1). For the amplification, we first isolated the total RNA from abdomens of newly emerged females using TRIzol reagent (Life Technologies) according to the manufacturer's instructions. Samples were treated with DNaseI Amplification Grad (Invitrogen) to eliminate contaminant genomic DNA. For the reverse transcription, we used $3 \mu \mathrm{g}$ of total RNA, Superscript III (Invitrogen), and Oligo $(\mathrm{dT})_{20}$ (Invitrogen), according to the manufacturer's instructions. PCR amplifications were done using Taq High Fidelity (Platinum ${ }^{\mathrm{TM}}$ Taq DNA Polymerase High Fidelity-Invitrogen), and the reaction conditions were according to the primer's pairs (Table S1). For the 3' region sequencing, a 3' RACE was made. To this end, cDNA was synthesized from total RNA of the carcass (abdomen without ovaries and intestine) of foundresses (extracted using Trizol methodology as described above) using the SuperScript II method and replacing Oligo dT (12-18) with an adapter primer: Adapter primer - 5'- GGCCACGCGTCGACTAGTAC
TTTTTTTTTTTTTTTTTTTTTTTT-3', containing the anchor sequence for the $3^{\prime}$ RACE PCR primer (Table S1). After PCRs, the amplified fragments were either purified using a PCR purification kit (PureLink TM Quick Gel Extraction and PCR Purification Combo Kit-Invitrogen) or sequenced directly $(2 \mu \mathrm{l}$ PCR product in a final volume of $10 \mu \mathrm{l} \mathrm{se-}$ quencing reaction). The sequencing was done at LaCTAD (UNICAMP-Campinas-SP) and at the Nucleus of Services in Biotechnology (NSB) from the Hemocenter Foundation (USP-Ribeirão Preto-SP), both with Sanger methodology, on ABI 3730XL (Applied Biosystems) and ABI 3500XL (Applied Biosystems) equipment, respectively. The C. tarsata cDNA vg sequence was deposited to GenBank under the accession number MW001205.

\subsection{In silico analysis of bee vitellogenins}

The Artemis platform version 16.0.0 (Rutherford et al. 2000) was used to manually annotate the structural organization of ORFs and putative exon/intron splice sites for vitellogenin of the following bee species: Apis dorsata (Ador), Apis florea (Aflo), Apis mellifera (Amel), Bombus impatiens (Bimp), Bombus terrestris (Bter), Duforea novaeangliae (Dnov), Exaerete mexicana (Emex), Euglossa dilemma (Edil), Friesiomellita varia (Fvar), Habropoda laboriosa (Hlab), Lasioglossum albipes (Lalb), and Melipona quadrifasciata (Mqua). Sequences were retrieved from the Hymenoptera Genome Database (http://hymenopteragenome.org), except $F$. varia vg (GenBank BioProject ID PRJNA528016, Freitas et al. 2020) and C. tarsata $v g$ (Ctar) (this study). We also used a partial $v g$ sequence from $C$. analis (Cana) (GenBank BioProject ID PRJNA490324, Falcon et al. 2019 ). Other sequences were retrieved from the NCBI: Apis cerana (Acer) (GenBank accession number MG775224.1), Osmia cornifrons (Ocor) (AIU68826.1), Megachile rotundata (Mrot) (XP_003703020.1), Bombus ignitus (Bign) (ACM $\bar{M} 46019.1$ ), and Bombus hypocrita (Bhyp) (ACU00433.1). The manual annotations were done because we observed some inconsistencies 
in the automatic annotation of the predicted sequences in the Hymenoptera Genome Database (annotated sequences are in Supplementary data 1). Vg amino acid sequences were imported to the MEGA program version X (Kumar et al. 2018) for building multiple sequence alignments (MUSCLE) and calculating and constructing phylogenetic trees. Phylogenetic analysis was performed using the neighbor-joining method under the Jones-Taylor-Thornton (JTT) matrix-based model (Jones et al. 1992). The rates between sites were treated as a gamma distribution. Bootstrap confidence limit probabilities were estimated from 1000 replications. Vitellogenin amino acid sequence of Nasonia vitripennis (Nvit) (XP_001607388.1) and Pimpla nipponica (Pnip) (AAC32024.1) were used as outgroups. The Vg tree was visualized using FigTree v1.4.4 (http://tree.bio.ed.ac.uk/software/figtree/). The modular domains of the Vgs were analyzed with the SMART program (http://smart.embl-heidelberg.de/) (Letunic and Bork 2017), using SMART mode: Normal, not filling the Sequence ID, and by searching for signal peptides.

The signal sequences of the Vgs were predicted using SignalP 5.0 (http://www.cbs.dtu. $\mathrm{dk} /$ services/SignalP), the N-glycosylation sites were predicted using the NetGly 1.0 Prediction Server (http://www.cbs.dtu.dk/services/NetNGlyc/), and the isoelectric points (pI) and molecular weights (Mw) were computed using $\mathrm{pI} / \mathrm{Mw}$ at Expasy (https://web.expasy.org/cgi-bin/compute_pi/pi_ tool). The prediction of protein three-dimensional (3-D) structure was performed using the protein homology/analogy recognition engine v 2.0 Phyre2 server (http://www.sbg.bio.ic.ac.uk/phyre2/) (Kelley et al. 2015).

\section{4. $v g$ expression for Centris tarsata and Centris analis using RT-qPCR}

For real-time quantitative PCR (qPCR), total RNA was isolated from whole larvae and pupae, from abdomens of newly emerged females and males, and from carcasses (abdomen without ovaries and intestine) and ovaries of foundress females using TRIzol protocol. Each sample corresponded to one individual. Samples were treated with DNaseI Amplification Grad
(Invitrogen) to eliminate contaminant genomic DNA. RNA concentration was determined by absorption at $260 \mathrm{~nm}$ using UV spectrophotometry. For reverse transcription, we used 1$5 \mu \mathrm{g}$ of total RNA of C. tarsata and $3 \mu \mathrm{g}$ of total RNA of $C$. analis, Superscript III (Invitrogen) and Oligo (dT) 20 (Invitrogen), according to the suppliers' protocol.

qPCR assays for $C$. tarsata were performed using the StepOnePlus ${ }^{\mathrm{TM}}$ Real-Time PCR System (Applied Biosystems). Amplification was carried out in a $20 \mu \mathrm{L}$ reaction volume, containing $10 \mu \mathrm{L}$ of SYBR Green Master Mix 2× (Applied Biosystems), $2 \mu \mathrm{L}$ of cDNA (diluted $5 \times$ ), and 4 pmol of each gene-specific primer, according to the manufacturer's instructions. The PCR conditions were $50{ }^{\circ} \mathrm{C}$ for $2 \mathrm{~min}$ and $95^{\circ} \mathrm{C}$ for $10 \mathrm{~min}$, followed by 40 cycles of $95^{\circ} \mathrm{C}$ for $15 \mathrm{~s}$, and $60{ }^{\circ} \mathrm{C}$ for $1 \mathrm{~min}$. Specific primers used for C. tarsata $v g$ amplification in qRT-PCR assays are in Table S2. Expression measurements of $v g$ were normalized relative to $r p L 32$ designed for Centris flavifrons (GenBank accession number JI020981.1) (primer sequences in Table S2). This gene is a suitable reference gene for normalization in gene expression analysis in Apidae bees (Lourenço et al. 2008; Freitas et al. 2019).

For $C$. analis expression analyses, qPCR assays were performed using the StepOne ${ }^{\mathrm{TM}}$ Real-Time PCR System (Applied Biosystems). Amplification was carried out in a $15 \mu \mathrm{L}$ reaction volume, containing $7.5 \mu \mathrm{L}$ of SYBR Green Master Mix $2 \times$ (Applied Biosystems), $2 \mu \mathrm{L}$ of cDNA (diluted $5 \times$ ), and 3 pmol of each gene-specific primer, according to the manufacturer's instructions. PCR conditions were the same as described above. Primers used for $C$. analis vg amplification in qPCR assays are in Table S2. Gene expression normalization was relative to rpL32 designed for $C$. analis (primer sequences in Table S2). rpL32 partial sequence was annotated using the raw sequences of RNA-Seq libraries (GenBank BioProject ID PRJNA490324) and deposited in GenBank (GenBank Accession no. BK013351). All primers were designed using Primer3 (http://bioinfo.ut.ee/primer3$0.4 .0 /)$. 
The specificity of each pair of primers was checked by melting curve analysis for all qPCR assays $\left(95{ }^{\circ} \mathrm{C}\right.$ for $15 \mathrm{~s}, 60{ }^{\circ} \mathrm{C}$ for $1 \mathrm{~min}$, and a continuous raise in temperature to $95{ }^{\circ} \mathrm{C}$ at $0.3{ }^{\circ} \mathrm{C} /$ s ramp rate followed by $95{ }^{\circ} \mathrm{C}$ for $\left.15 \mathrm{~s}\right)$. PCR efficiency values $(E)$ were calculated for each pair of primers and bee species from the given slope after running standard curves and following the formula $E=(10(-1 /$ slope $)-1) \times 100$ (Table S2)

Data were analyzed according to the comparative threshold cycle $(\mathrm{Ct})$ method, where the relative quantification is given by the amount of a target transcript, normalized to an endogenous reference gene, relative to a calibrator, and primer efficiencies (Pfaffl 2001). To check reproducibility, each biological sample was run in technical triplicate, and outliers were removed according to the default analysis settings from the StepOne ${ }^{\mathrm{TM}}$ software v 2.3.

\subsection{Protein profile by SDS-PAGE electrophoresis}

Protein profiles were performed using hemolymph and ovaries of $C$. tarsata foundresses. Hemolymph was collected after immobilization on ice; a small hole was made in the abdomen (between terga III and IV in the right side) and $4 \mu \mathrm{L}$ of saline $0.9 \%$ was introduced with a micropipette $(0.5-10 \mu \mathrm{L}$ tip). Then, ca. $2 \mu \mathrm{L}$ of the diluted hemolymph was collected in the same hole using a micropipette. The hemolymph was kept at $-20{ }^{\circ} \mathrm{C}$ until use. Ovaries were macerated in $15 \mu \mathrm{L}$ of saline $0.9 \%$ and then diluted $2 \times, 5 \times$, and $10 \times$ in double distilled water. As a positive control for protein profile, especially the molecular size of Vg (180 kDa; Wheeler and Kawooya 1990), we also used hemolymph from nurses and newly emerged bees ( $\leq 24 \mathrm{~h}$ old) of $A$. mellifera from a queenright colony from the apiary at Ribeirão Preto. Nurse bees were collected from the brood area, feeding the larvae. For this species, hemolymph was extracted directly from a small hole in the abdomen, and then diluted $10 \times$ in saline $0.9 \%$. Aliquots of $0.5 \mu \mathrm{l}$ diluted hemolymph and $1 \mu \mathrm{l}$ of the ovarian sample $(2 \times, 5 \times$, and $10 \times$ dilutions) were analyzed by SDS-PAGE following Laemmli (1970). Electrophoresis was performed at $15 \mathrm{~mA}$ and $7-10{ }^{\circ} \mathrm{C}$, using $10 \%$ polyacrylamide gels $(100 \times 100 \times 1 \mathrm{~mm})$. Gels were stained with silver nitrate (Caetano-Anollés and Gresshoff 1994).

\subsection{Statistical analysis}

The differences in gene expression throughout development were determined by the nonparametric Kruskal-Wallis and Dunn's post hoc test for multiple comparisons. Gene expression differences between tissues, sexes, and older/ younger bees were analyzed using the nonparametric Mann-Whitney test. Analyses were performed with PAST 3.26 software (Hammer et al. 2001). The sample size is given in the relevant figures.

\section{RESULTS}

\section{1. cDNA sequence of $C$. tarsata and C. analis vitellogenin, and amino acid sequence comparisons}

cDNA sequencing of C. tarsata vitellogenin recovered a $5391 \mathrm{bp}$ long sequence with an open reading frame of $5331 \mathrm{bp}$, encoding a 1777 amino acid fragment, with a calculated molecular weight of $199.5 \mathrm{kDa}$ and theoretical isoelectric point (pI) of 6.67. The amino acid sequence contained a p r e d i c t e d s i g n a 1 p e p t i d e (MWLPLTLLVLAGTVSA) at the N-terminus, two N-glycosylation sites, five putative cleavage sites showing the RXXR/S consensus, and the conserved motifs DGKR and GLCG at position 1582-1585 and 1600-1603, respectively, followed by nine cysteines near the $\mathrm{C}$-terminus (Figure S2A). These domains were present in all bees analyzed here (Figure S3). The partial cDNA sequence of $C$. analis $v g$ is $5253 \mathrm{bp}$ long, with an open reading frame of $5219 \mathrm{bp}$. This partial sequence, encoding a 1739 amino acid fragment, contained a predicted signal peptide (MWLPVTLLVLAATVSA) at the N-terminus, two N-glycosylation sites, four putative cleavage sites showing the RXXR/S consensus, the conserved motifs DGKR and GLCG at position 1584-1587 and 1602-1605, and eight cysteines near the C-terminus (Figure S2B). 
During manual annotation of $v g$ from sequenced bee genomes (Supplementary data 1), no evidence of Vg gene duplication was observed, suggesting that all bees have only one gene for this protein.

Protein-protein BLAST to other bee species showed its highest similarities to solitary bee Vgs $(57.25 \%$ to Habropoda laboriosa, $57.09 \%$ to Osmia cornifrons, $57.38 \%$ to Megachile rotundata, and $55.54 \%$ to Duforea novaeangliae) and lowest similarities to Melipona quadrifasciata Vg (50.54\%). A phylogenetic analysis of the amino acid sequences revealed that the Vgs of Apidae bees form a cluster, separately from Megachilidae and Halictidae bees, and the Vg from Centris bees forms a sister group with other Apidae solitary bee, H. laboriosa (Figure 1A). The amino acid sequence of $C$. tarsata $\mathrm{Vg}$ was compared with other 18 bee Vgs, and the main conserved motifs found in Vgs were present (Lipoprotein N-terminal-LPD_N, DUF1943 and Von Willebrand factor type $\overline{\mathrm{D}}$-VWD; Figure 1B).

High similarities were also observed in 3-D structural prediction between $C$. tarsata and C. analis $\mathrm{Vgs}$ (primary sequences with $77 \%$ a

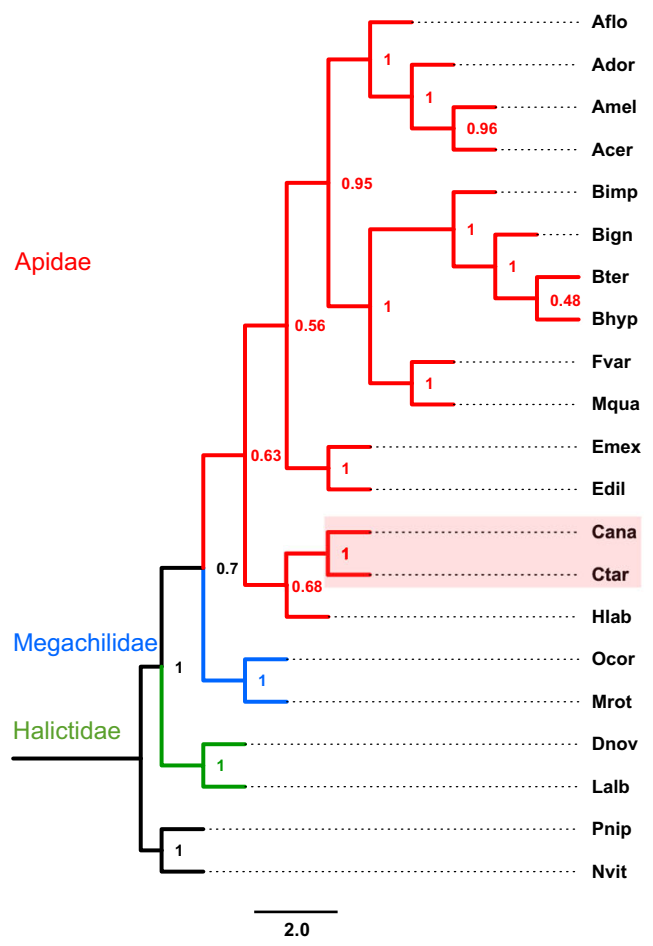

b

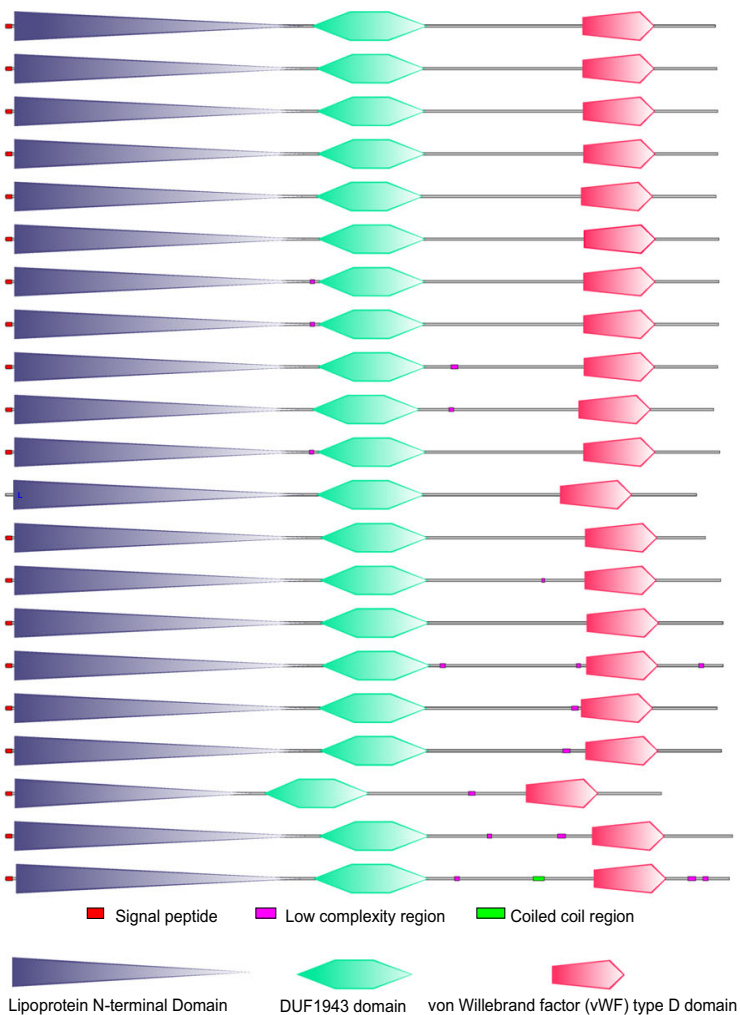

Figure 1. (a) Phylogenetic analysis of amino acid sequences of Vitellogenins of Apidae, Megachilidae, and Halictidae bees. Numbers on the branches of the phylogenetic trees represent bootstrap values for the 1000 bootstrap replicates. Nasonia vitripennis Vg and Pimpla nipponica Vg were used as outgroups. (b) Common features and typical domains of the primary structures of Vitellogenins from bee species represented in (a). Acer, Apis cerana; Ador, Apis dorsata; Aflo, Apis florea; Amel, Apis mellifera; Bhyp, Bombus hypocrita; Bing, Bombus ignitus; Bimp, Bombus impatiens; Bter, Bombus terrestris; Cana, Centris analis; Ctar, Centris tarsata; Dnov, Duforea novaeangliae; Emex, Exaerete mexicana; Edil, Euglossa dilemma; Fvar, Friesiomellita varia; Hlab , Habropoda laboriosa; Lalb, Lasioglossum albipes; Mqua, Melipona quadrifasciata; Mrot, Megachile rotundata; Nvit, Nasonia vitripennis; Ocor, Osmia cornifrons; Pnip, Pimpla nipponica. Bootstrap values for each node are shown. 
similarities), and these to A. mellifera $\mathrm{Vg}$ (primary sequences with $55 \%$ similarities; Figure 2).

Analyzing the protein profile of hemolymph and ovaries of $C$. tarsata, we observed a $180 \mathrm{kDa}$ band corresponding to $\mathrm{Vg}$ (Figure 3). As expected, $\mathrm{Vg}$ was the most abundant protein in the ovaries of foundress bees (Figure 3).

\subsection{Expression of vitellogenin throughout development, in tissues and between sexes}

$v g$ transcripts of C. tarsata were quantified in two larval and two pupal stages, newly emerged adult females, and two groups of foundress female adults (Figure 4). The results showed that expression can be detected from spinning larvae and then was continuously detected during the pupal stages and in adulthood. Relatively low expression was observed in larval and pupal stages, and transcript amounts increased up to 98-fold at emergence time when compared with the larval and pupal stages (NE versus $\mathrm{LS}, \mathrm{Pw}$, and $\mathrm{Pb}$, Kruskal-Wallis, Dunn's post hoc, $p<0.001$ ). Foundress females had 180-fold more expression than newly emerged bees (NE versus FF, KruskalWallis, Dunn's post hoc, $p=0.025$; Figure 4).

Comparing tissues, $v g$ expression was also detected in the ovaries of foundress females of C. tarsata with expression 9000-fold lower than in the fat body (Mann-Whitney, $p=0.012$; Figure 5A). Foundress of $C$. analis showed $v g$ expression in the fat body, but no expression was observed in the ovaries (Figure 5B). Newly emerged males from both bee species also exhibited expression of $v g$. Although $v g$ expression was 3.5- and 2-fold higher in females than in males of C. tarsata and C. analis, respectively, no significant differences were detected (MannWhitney, $p>0.05$; Figure 5A, B).

\subsection{Levels of vitellogenin in newly emerged bees from the same nest}

Here, we analyzed two newly emerged females of $C$. tarsata from the same nest collected at the same time, and thus with few hours of difference in development (Figure S1). In all four nests, the younger bee (closer to the nest entrance) had more $v g$ transcript amount than the older (Mann-Whitney, $p=0.03$; Figure 6 ). This result indicates that the amount of $v g$ is related to bee developmental time, as the younger bees are in advanced development to emerge earlier.

\section{DISCUSSION}

In this study, we provided a phylogenetic comparison of Vg across several bee species and described the predicted protein structure of $\mathrm{Vg}$ in the solitary bees $C$. tarsata and C. analis . Moreover, we analyzed the expression profile of $v g$ throughout development, in different tissues and sexes, and its activation after female emergence.

The amino acid sequence of Centris contains all three domains, LPD_N, VWD, and DUF1943,
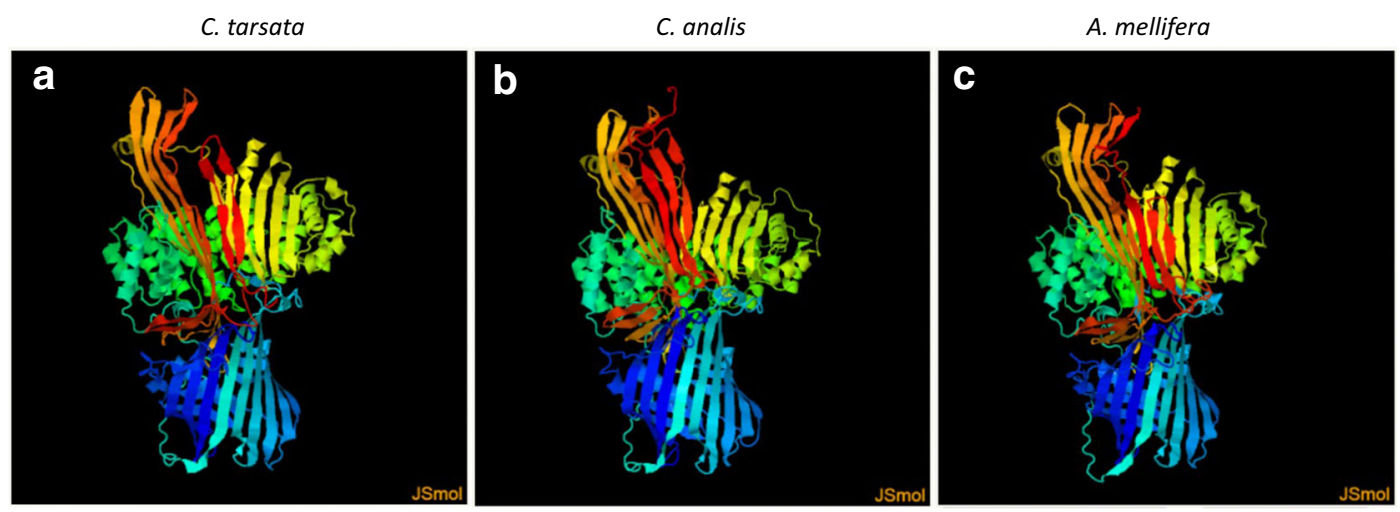

Figure 2. Vitellogenin 3-D structural prediction of (a) Centris tarsata, (b ) Centris analis, and (c) Apis mellifera using the Phyre2 server. The best fit was lipovitellin (PBD-ID c1lshA). Image colored by rainbow $\mathrm{N} \rightarrow \mathrm{C}$-terminus. 


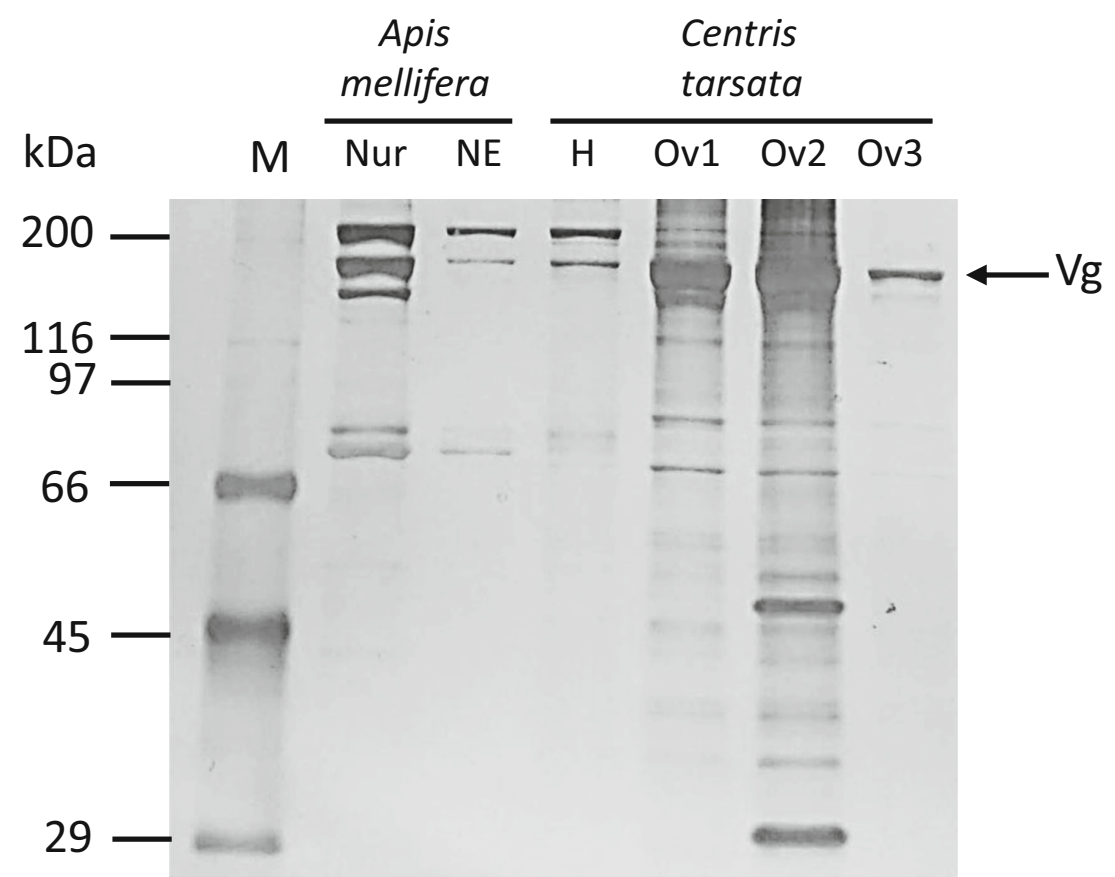

Figure 3. Silver nitrate-stained $10 \%$ SDS-PAGE gel from samples of hemolymph of nurse (Nur) and newly emerged (NE) Apis mellifera workers, and hemolymph $(\mathrm{H})$ and ovaries (Ov1: diluted 5×, Ov2: diluted 2×, Ov3: diluted 10×) of Centris tarsata foundresses. M: protein molecular weight marker (SIGMA-ALDRICH®/SDS6H2) indicated in $\mathrm{kDa}$. Vitellogenin yolk protein ( $\mathrm{Vg}: \sim 180 \mathrm{kDa})$ is indicated in the image.

that are highly conserved in insects (Tufail and Takeda 2008; Shen et al. 2019). Additionally, we identified the motifs GL/ICG and DGXR at the Cterminus, which are also conserved in insects

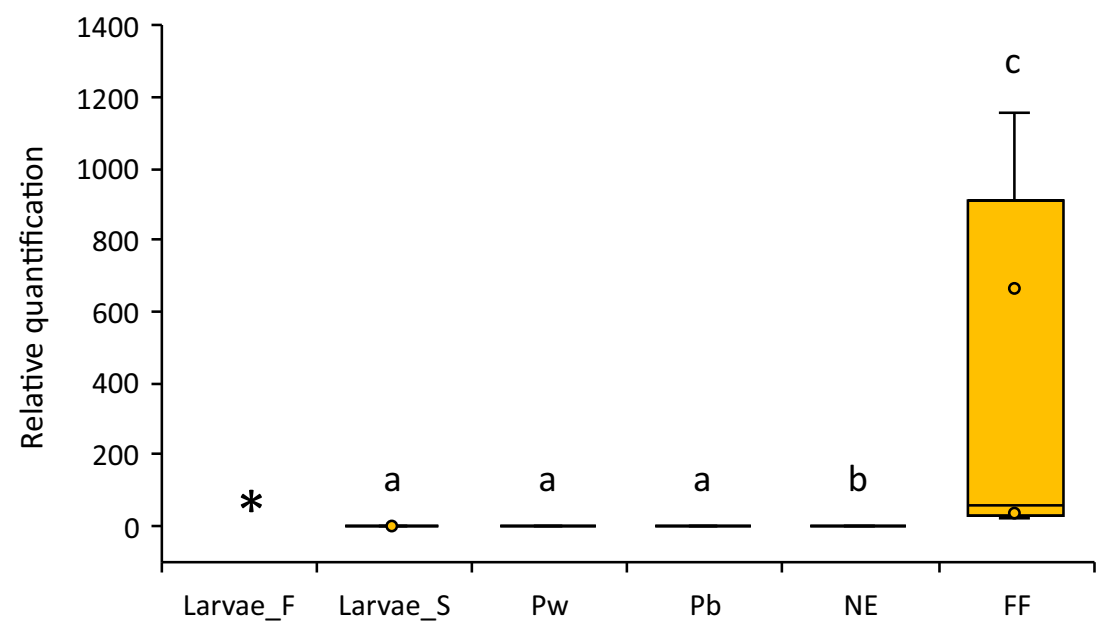

Figure 4. Expression of vitellogenin by qPCR throughout the development of Centris tarsata: feeding larvae (Larvae_F; $n=3$ ), spinning larvae (Larvae_S; $n=3$ ), white-eyed pupae ( $\mathrm{Pw} ; n=3)$, brown-eyed pupae $(\mathrm{Pb} ; n=3)$, newly emerged females (NE; $n=15$ ), and foundress females (FF; $n=5$ ). Box plots show medians (horizontal lines), 25 th to 75 th percentiles (boxes), and the minimum value and maximum value (whiskers). The circles indicate internal points. Asterisk indicates no expression. Different letters indicate significant differences $(p<0.05)$. 
a

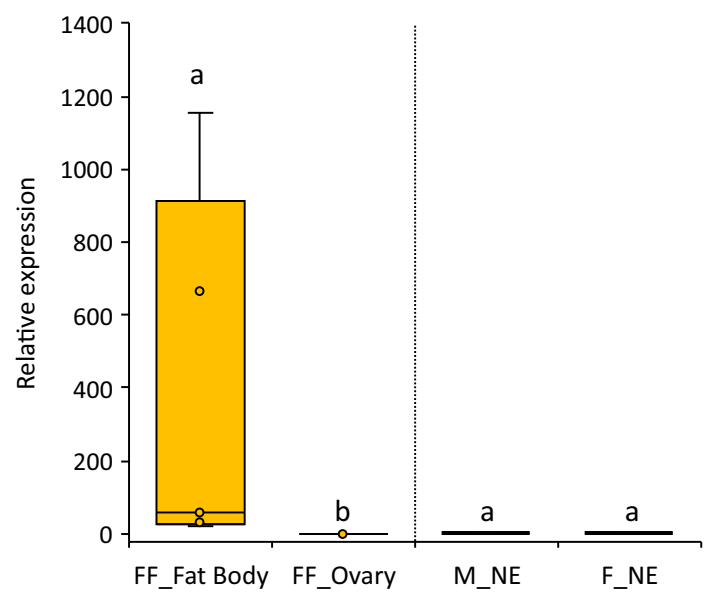

b

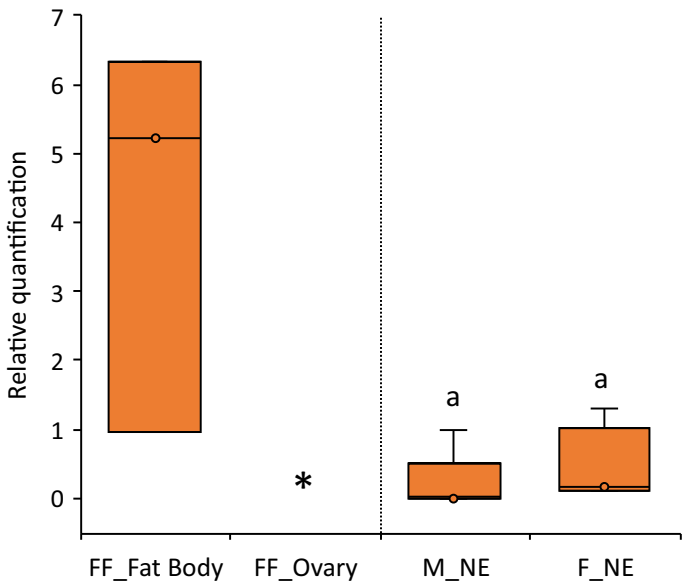

Figure 5. Expression of vitellogenin by qPCR in tissues and sexes of (a) Centris tarsata and (b) Centris analis . Foundress fat body (FF_Fat Body, C. tarsata: $n=5 ; C$. analis : $n=3$ ), foundress ovaries (FF Ovary, C. tarsata : $n=5$, C. analis $n=3$ ), newly emerged males (M_NE, C. tarsata: $n=3, C$. analis $: n=5$ ), and newly emerged females (F_NE, C. tarsata: $n=7$, C. analis : $n=4$ ). Box plots show medians (horizontal lines), 25th to 75th percentiles (boxes), and the minimum value and maximum value (whiskers). The circles indicate internal points. Asterisk indicates no expression. Different letters indicate significant differences $(p<0.05)$.

(Tufail and Takeda 2008). These conserved domains and motifs were observed in the $\mathrm{Vg}$ from all
19 bees analyzed here. Molecular evolution analyses of A. mellifera $\mathrm{Vg}$ revealed that the $\mathrm{N}$ -

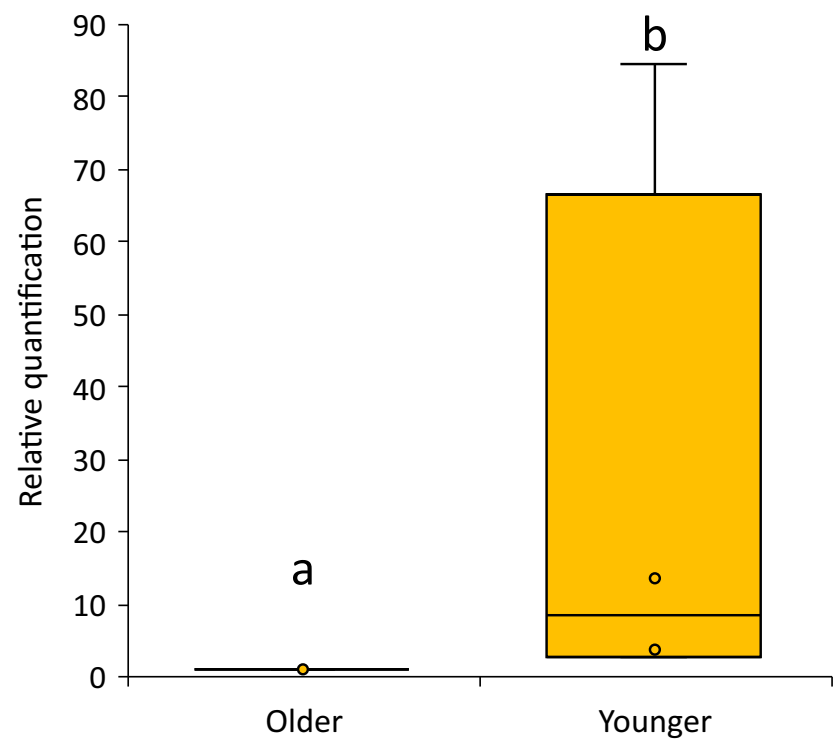

Figure 6. vitellogenin expression by qPCR of newly emerged female sisters (older and younger) of Centris tarsata from four different nests $(n=4)$. Box plots show medians (horizontal lines), 25 th to 75 th percentiles (boxes), and the minimum value and maximum value (whiskers). The circles indicate internal points. Different letters indicate significant differences $(p<0.05)$. 
terminal domain is resistant to change, while nonsynonymous mutations are enriched of the remaining part of the protein, which is associated with lipid binding (Kent et al. 2011). These results suggested that the N-terminal domain is central to conserved function in reproduction, while the remaining protein has been freer to evolve, and that these polymorphisms can alter ligand-binding properties of Vg (Havukainen et al. 2011; Kent et al. 2011). However, selective pressure remains to be investigated on $\mathrm{Vg}$ between solitary and social species.

It is interesting to note that the amino acid sequence (BLASTp) of the $\mathrm{Vg}$ from $C$. tarsata was more similar to that more distantly related solitary bees than to that of more closely related social Apidae. However, the inferred phylogenetic tree (gene tree) resulted in Centris as the sister group of corbiculate bees, and the overall topology was very similar from molecular bee phylogenies (Cardinal and Danforth 2013; Romiguier et al. 2016; Bossert et al. 2019).

We observed that $v g$ expression in C. tarsata began in spinning larvae and it was maintained until the adult phase, albeit at very low levels. Due to its relevance to the social organization (Amdam et al. 2003; Nelson et al. 2007), vg has mainly been investigated in the social bees: A. mellifera (Barchuk et al. 2002; Piulachs et al. 2003; Guidugli et al. 2005), A. cerana (Zhang et al. 2017), Frieseomelitta varia, Melipona quadrifasciata, Scaptotrigona postica (Dallacqua et al. 2007), B. ignitus (Lee et al. 2009), and B. hypocrita (Li et al. 2010). However, its temporal expression in related solitary bees has largely neglected (with the exception of: Lee et al. 2015; O. cornifrons). Larval $v g$ expression is likewise understudied. Larval $v g$ transcripts have been previously only been detected in the eusocial A. mellifera (Guidugli et al. 2005) and A. cerana (Zhang et al. 2017), yet never before in a solitary bee (Lee et al. 2015). Detection of $v g$ during the larval stage in A. mellifera (Guidugli et al. 2005), A. ceranae (Zhang et al. 2017), and C. tarsata (this study) may reflect its role as a multifunctional protein during this stage and may suggest a shared feature for the Apidae family. Storage proteins are ecologically important gene products playing a role in diapause (Hunt et al. 2007). In solitary bees, this arrest of development occurs mainly during the last larval instar (prepupal stage), and this developmental diapause has been lost in social bees (Santos et al. 2019). The shift from developmental diapause in the solitary ancestor to adult, reproductive, or absence of diapause in social lineages suggests a role of diapause in the evolution of sociality in bees (Santos et al. 2019). In Apidae, Centridini bees comprise only solitary bees being a sister group of the corbiculate bees (Euglossini, Bombini, Meliponini, and Apini; Bossert et al. 2019) where sociality evolved as well as different forms of diapause (adult, reproductive, or absence of diapause). Prepupal diapause was observed in C. tarsata during the dry season (Aguiar and Garófalo 2004). Although O. cornifrons is a solitary bee, diapause occurs in the adult stage, and $v g$ was continuously expressed during diapause stage but not in larvae or prepupae (Lee et al. 2015). These results suggest that $v g$ expression in larva may be a retained evolutionary trait from the Apidae ancestor as an important storage protein for diapause. Therefore, more studies of the expression of $v g$ during larval stages in bees with different social levels of behavior are needed. Pupal expression of $v g$ was observed at lower levels in the last and middle pupal stages in workers and queens of A. mellifera, respectively (Barchuk et al. 2002; Piulachs et al. 2003; Guidugli et al. 2005). In workers and queens of $B$. hypocrita, vg was detected during all pupal stages, with a gradual increase from initial to late pupal stages (Li et al. 2010); however, in the congeneric bee $B$. ignitus, $v g$ was first detected only in the late pupal stage (Lee et al. 2009). We did not investigate $v g$ expression in the late pupal stage, but the detection in pupae, especially in increased amounts near the time of bee emergence, may be important for preparing females for the onset of reproduction. In fact, $v g$ expression in egg-laying social bees (queens and workers; Piulachs et al. 2003; Li et al. 2010) or solitary bees (Lee et al. 2015 and this study) are much higher, consistent with its primary function as an egg yolk protein. 
Comparing the expression of $v g$ between ovary and carcass (including the fat body), levels were higher in the latter for both $C$. tarsata and $C$. analis . This result was similar to that obtained in A. mellifera (Guidugli et al. 2005) and A. cerana (Zhang et al. 2017), which also showed that $v g$ transcript levels were higher in fat body tissue. In fact, the fat body of insects is the main organ of the production of $v g$ (Bellés 2004), although other tissues may express the gene encoding $\mathrm{Vg}$, such as ovaries (Guidugli et al. 2005). Traces of $v g$ expression were only observed in the ovaries of $C$. tarsata .

The presence of $v g$ expression in C. tarsata and $C$. analis males was also observed, although in smaller amounts, as observed in all studied male bees so far (Piulachs et al. 2003; Guidugli et al. 2005; Dallacqua et al. 2007; Li et al. 2010). Expression in males possibly relates to $\mathrm{Vg}$ having many functions in insects other than reproduction, i.e., it is used to transport molecules such as sugar, lipids, phosphates, vitamins, and hormones, as well as participating in immune functions as a zinc carrier (Sappington and Raikhel 1998; Amdam et al. 2004b).

Mating has a profound effect on social Hymenoptera, where mated queens produce high amounts of $v g$ in ants (Tian et al. 2004; Chérasse et al. 2019) and bees (Kocher et al. 2008). Moreover, mating accelerates queen oogenesis in social bees such as in Melipona quadrifasciata (Martins and Serrão 2004; de Souza et al. 2007; Tanaka and Hartfelder 2009) and A. mellifera (Tanaka and Hartfelder 2004; Tanaka et al. 2006). Alternately, mating in the solitary bee Osmia bicornis does not affect ovary activation or the rate of reproduction over time (Van Eeckhoven and Duncan 2020). The authors using morphology (oocyte volume and position) observed that the rate of oogenesis increased over time in both mated and unmated females, suggesting that oogenesis initiates and accelerates regardless of mating status (Van Eeckhoven and Duncan 2020). Supporting this observation, $v g$ expression increases in the first hours after emergence, reaching its maximum in $72 \mathrm{~h}$ in another solitary bee, O. cornifrons (Lee et al. 2015). This increase in $v g$ expression may lead to the maturation of the oocytes even in unmated females. For instance, the first fully mature oocytes were observed $96 \mathrm{~h}$ after $O$. bicornis emergence (Van Eeckhoven and Duncan 2020). Here, we studied sister females, i.e., females from the same nest, that were collected at the same time, but with differences in maturation: older females were located towards the back of the nest and were less mature than their sisters (younger females). As the less mature has a difference of a few hours from the more mature ones, the higher $v g$ expression observed in more mature females indicates that the increase of $v g$ occurs rapidly (on the order of hours), even in unmated females, which reinforces the idea that mating does not influence the onset of oogenesis nor its acceleration in solitary bees as it does in social Hymenoptera (Van Eeckhoven and Duncan 2020).

Within the Apidae, diverse levels of sociality are found, making it a critical group for studying sociality. The Vgs of social species are better studied, but this is the first work characterizing the expression profile of $v g$ in solitary Apidae. Its characterization is important to establish the relation of Vgs of bees, and ultimately to examine their relation to sociality.

\section{ACKNOWLEDGMENTS}

We are grateful to Fernanda Batista Santos for helping with primer design, Dr. Tiago Falcón Lopes and Prof. Márcia MG Bitondi for the Centris analis vitellogenin cDNA sequence, and Vera Figueiredo for helping with the $C$. analis nests. We thank $\mathrm{S}$. Hollis Woodard for critically reading and commenting on previous versions of this manuscript, and two anonymous reviewers for their constructive suggestions and comments. We thank the Centro Integrado de Pós-Graduação e Pesquisa em Saúde at the Universidade Federal dos Vales do Jequitinhonha e Mucuri, Diamantina, MG, for providing equipment and technical support for experiments, and the staff of the Life Sciences Core Facility (LaCTAD) from State University of Campinas (UNICAMP) and of the Nucleus of Services in Biotechnology (NSB) from Hemocenter Foundation (USP-Ribeirão Preto-SP) for DNA sequencing. Individuals were sampled under the SISBIO license numbers 37384 and 64885 . 


\section{AUTHOR CONTRIBUTIONS}

APL designed the study; APL, JCA, CPC, JTF, $A C D$, and NPG performed experiments and analysis; APL, JCA, ZLP, and CPC interpreted the data, wrote the paper, and participated in the revisions of it.Funding

This work was supported by Fundação de Amparo à Pesquisa do Estado de Minas Gerais FAPEMIG (CBB - APQ-02514-14, CBB- PPM00225-16), Fundação de Amparo à Pesquisa do Estado de São Paulo - FAPESP (2016/06657-0), Conselho Nacional de Desenvolvimento Científico e Tecnológico (CNPq; scholarship for JCA, NPG, and JTF), and Coordenação de Aperfeiçoamento de Pessoal de Nível Superior Brasil (CAPES) - Finance Code 001 (scholarship for $\mathrm{ACD})$.

\section{COMPLIANCE WITH ETHICAL STANDARDS}

Conflict of interest The authors declare that they have no conflict of interest.

Vitellogénine des abeilles solitaires Centris tarsata et Centris analis (Hymenoptera : Apidae) : analyse structurelle de l'ADNc et expression des genes.

Vitellogénine / expression génétique / mâle / ovaires.

Vitellogenin der solitären Bienen Centris tarsata und Centris analis (Hymenoptera: Apidae): Analysen der cDNA-Struktur und der Genexpression.

Vitellogenin / Genexpression / Männchen / Ovarien.

\section{REFERENCES}

Aguiar, C.M.L., Garófalo, C.A. (2004) Nesting biology of Centris (Hemisiella) tarsata Smith (Hymenoptera, Apidae, Centridini). Rev Bras Zool 21, 477-486. https://doi.org/10.1590/S0101-81752004000300009

Alonso, J.D.S., Silva, J.F., Garófalo, C.A. (2012) The effects of cavity length on nest size, sex ratio and mortality of Centris (Heterocentris ) analis
(Hymenoptera, Apidae, Centridini). Apidologie 43, 436-448. https://doi.org/10.1007/s13592-011-0110-0

Amdam, G.V., Omholt, S.W. (2003) The hive bee to forager transition in honeybee colonies: The double repressor hypothesis. J Theor Biol 223, 451-464. https://doi.org/10.1016/S0022-5193(03)00121-8

Amdam, G.V., Page, R.E. (2010) The developmental genetics and physiology of honeybee societies. Anim Behav 79, 973-980. https://doi.org/10.1016/j. anbehav.2010.02.007

Amdam, G.V., Norberg, K., Hagen, A., Omholt, S.W. (2003) Social exploitation of vitellogenin. Proc Natl Acad Sci 100, 1799-1802. https://doi.org/10.1073 /pnas.0333979100

Amdam, G.V., Norberg, K., Fondrk, M.K., Page, R.E. (2004a) Reproductive ground plan may mediate colony-level selection effects on individual foraging behavior in honey bees. Proc Natl Acad Sci 101, 1135011355. https://doi.org/10.1073/pnas.0403073101

Amdam, G.V., Simões, Z.L.P., Hagen, A. et al. (2004b) Hormonal control of the yolk precursor vitellogenin regulates immune function and longevity in honeybees. Exp Gerontol 39, 767-773. https://doi. org/10.1016/j.exger.2004.02.010

Araújo, P.C.S., Lourenço, A.P., Raw, A. (2016) Trapnesting bees in montane grassland (campo rupestre) and cerrado in Brazil: collecting generalist or specialist nesters. Neotrop Entomol 45, 482-489. https://doi. org/10.1007/s13744-016-0395-9

Barchuk, A.R., Bitondi, M.M.G., Simões, Z.L.P. (2002) Effects of juvenile hormone and ecdysone on the timing of vitellogenin appearance in hemolymph of queen and worker pupae of Apis mellifera. J Insect Sci 2, 1-8. https://doi.org/10.1673/031.002.0101

Batra, S.W. (1984) Solitary bees. Sci. Am. 250, 120-127. https://doi.org/10.1038/scientificamerican0284-120

Bellés, X. (2004) Vitellogenesis directed by juvenile hormone. In Raikhel A.S. (Ed.), Reproduction biology of invertebrates: progress in vitellogenesis (pp. 157-197). Science Publishers Inc., Boca Raton

Bossert, S., Murray, E.A., Almeida, E.A.B. et al. (2019) Combining transcriptomes and ultraconserved elements to illuminate the phylogeny of Apidae. Mol Phylogenet Evol 130, 121-131. https://doi. org/10.1016/j.ympev.2018.10.012

Caetano-Anollés, G., Gresshoff, P.M. (1994) Staining nucleic acids with silver: an alternative to radioisotopic and fluorescent labeling. Promega Notes Mag 45, 1320

Cardinal, S., Danforth, B.N. (2013) Bees diversified in the age of eudicots. Proc R Soc B Biol Sci 280, 20122686. https://doi.org/10.1098/rspb.2012.2686

Carducci, F., Biscotti, M.A., Canapa, A. (2019) Vitellogenin gene family in vertebrates: evolution and functions. Eur Zool J 86, 233-240. https://doi.org/10.1080 $/ 24750263.2019 .1631398$

Chérasse, S., Dacquin, P., Aron, S. (2019) Mating triggers an up-regulation of vitellogenin and defensin in ant 
queens. J Comp Physiol A Neuroethol Sensory, Neural, Behav Physiol 205, 745-753. https://doi. org/10.1007/s00359-019-01362-0

Dallacqua, R.P., Simões, Z.L.P., Bitondi, M.M.G. (2007) Vitellogenin gene expression in stingless bee workers differing in egg-laying behavior. Insectes Soc 54, 7076. https://doi.org/10.1007/s00040-007-0913-1

de Souza, E.A., Neves, C.A., de Oliveira Campos, L.A. et al. (2007) Effect of mating delay on the ovary of Melipona quadrifasciata anthidioides (Hymenoptera: Apidae) queens. Micron 38, 471-477. https://doi. org/10.1016/j.micron.2006.08.005

Engels, W., Kaatz, H., Zillikens, A. et al. (1990) Honey bee reproduction: vitellogenin and caste-specific regulation of fertility. In Hoshi M., Yamashita O. (Eds.), Advances in invertebrate reproduction 5 (pp. 495-502). Elsevier Science Publishers B.V. (Biomedical Division), Amsterdam

Falcon, T., Pinheiro, D.G., Ferreira-Caliman, M.J. et al. (2019) Exploring integument transcriptomes, cuticle ultrastructure, and cuticular hydrocarbons profiles in eusocial and solitary bee species displaying heterochronic adult cuticle maturation. PLoS One 14, e0213796. https://doi.org/10.1371/journal. pone. 0213796

Freitas, F.C.P., Depintor, T.S., Agostini, L.T. et al. (2019) Evaluation of reference genes for gene expression analysis by real-time quantitative PCR (qPCR) in three stingless bee species (Hymenoptera: Apidae: Meliponini). Sci Rep 9, 17692. https://doi. org/10.1038/s41598-019-53544-0

Freitas, F.C.P., Lourenço, A.P., Nunes, F.M.F. et al. (2020) The nuclear and mitochondrial genomes of Frieseomelitta varia - a highly eusocial stingless bee (Meliponini) with a permanently sterile worker caste. BMC Genomics 21, 386. https://doi.org/10.1186 /s12864-020-06784-8

Garófalo, C.A., Martins, C.F., Alves-dos-Santos, I. (2004) The Brazilian solitary bee species caught in trap nests. In Freitas B.M. (Ed.), Solitary bees: conservation, rearing and management for pollination (pp. 77-84). Imprensa Universitária, Fortaleza

Garófalo, C.A., Martins, C.F., de Aguiar, C.M.L. et al. (2012) As abelhas solitárias e perspectivas para seu uso na polinização no Brasil. In Imperatriz-Fonseca V.L., Canhos D.A.L., de Alves D.A., Saraiva A.M. (Eds.), Polinizadores no Brasil: contribuição e perspectivas para a biodiversidade, uso sustentável, conservação e serviços ambientais (pp. 183-202). Editora da Universidade de São Paulo, São Paulo

Guidugli, K.R., Piulachs, M.-D., Bellés, X. et al. (2005) Vitellogenin expression in queen ovaries and in larvae of both sexes of Apis mellifera. Arch Insect Biochem Physiol 59, 211-218. https://doi.org/10.1002 /arch.20061

Guidugli-Lazzarini, K.R., do Nascimento, A.M., Tanaka, É.D. et al. (2008) Expression analysis of putative vitellogenin and lipophorin receptors in honey bee (Apis mellifera L.) queens and workers. J Insect Physiol 54,
1138-1147. https://doi.org/10.1016/j. jinsphys.2008.04.021

Hammer, Ø., Harper, D.A.T., Ryan, P.D. (2001) PAST: paleontological statistics software package for education and data analysis. Palaeontol Electron. 4, 1-9

Harnish, D.G., White, B.N. (1982) Insect vitellins: identification, purification, and characterization from eight orders. J Exp Zool 220, 1-10. https://doi.org/10.1002 /jez.1402200102

Hartfelder, K., Engels, W. (1998) Social Insect Polymorphism: Hormonal Regulation of Plasticity in Development and Reproduction in the Honeybee. In Pedersen R.A., Schatten G.P. (Eds.), Current Topics in Developmental Biology (pp. 45-77). Academic Press

Harwood, G., Amdam, G., Freitak, D. (2019) The role of Vitellogenin in the transfer of immune elicitors from gut to hypopharyngeal glands in honey bees (Apis mellifera ). J Insect Physiol 112, 90-100. https://doi. org/10.1016/j.jinsphys.2018.12.006

Havukainen, H., Halskau, Ø., Amdam, G.V. (2011) Social pleiotropy and the molecular evolution of honey bee vitellogenin. Mol Ecol 20, 5111-5113. https://doi. org/10.1111/j.1365-294X.2011.05351.x

Hunt, J.H., Kensinger, B.A., Kossuth, J. et al. (2007) A diapause pathway underlies the gyne phenotype in Polistes wasps, revealing an evolutionary route to castecontaining insect societies. Proc Natl Acad Sci USA 104, 14020-14025. https://doi.org/10.1073 /pnas.0705660104

Jones, D.T., Taylor, W.R., Thornton, J.M. (1992) The rapid generation of mutation data matrices from protein sequences. Bioinformatics 8, 275-282. https://doi. org/10.1093/bioinformatics/8.3.275

Kapheim, K.M., Pan, H., Li, C. et al. (2015) Social evolution. Genomic signatures of evolutionary transitions from solitary to group living. Science 348, 11391143. https://doi.org/10.1126/science.aaa4788

Kelley, L.A., Mezulis, S., Yates, C.M. et al. (2015) The Phyre 2 web portal for protein modeling, prediction and analysis. Nat Protoc 10, 845-858

Kent, C.F., Issa, A., Bunting, A.C., Zayed, A. (2011) Adaptive evolution of a key gene affecting queen and worker traits in the honey bee, Apis mellifera. Mol Ecol 20, 5226-5235. https://doi.org/10.1111/j.1365294X.2011.05299.x

Kocher, S.D., Richard, F.J., Tarpy, D.R., Grozinger, C.M. (2008) Genomic analysis of post-mating changes in the honey bee queen ( Apis mellifera ). BMC Genomics 9 , 1-15. https://doi.org/10.1186/1471-2164-9-232

Krombein, K.V. (1967) Wasps and bees life histories nests and associates. Smithsonian Press, Washington, D.C.

Kumar, S., Stecher, G., Li, M. et al. (2018) MEGA X: Molecular evolutionary genetics analysis across computing platforms. Mol Biol Evol 35, 1547-1549. https://doi.org/10.1093/molbev/msy096

Laemmli, U.K. (1970) Cleavage of structural proteins during the assembly of the head of bacteriophage T4. Nature 227, 680-685. https://doi.org/10.1038/227680 a0 
Lee, K.Y., Yoon, H.J., Lee, S.B. et al. (2009) Molecular cloning and characterization of a vitellogenin of the bumblebee Bombus ignitus . Int J Ind Entomol 18, 3340

Lee, K.Y., Yoon, H.J., Jin, B.R. (2015) Osmia cornifrons vitellogenin: CDNA cloning, structural analysis and developmental expression. Entomol Res 45, 94-101. https://doi.org/10.1111/1748-5967.12098

Letunic, I., Bork, P. (2017) 20 years of the SMART protein domain annotation resource. Nucleic Acids Res 46, D493-D496. https://doi.org/10.1093/nar/gkx922

Li, J., Huang, J., Cai, W. et al. (2010) The vitellogenin of the bumblebee, Bombus hypocrita: studies on structural analysis of the cDNA and expression of the mRNA. J Comp Physiol B 180, 161-170. https://doi. org/10.1007/s00360-009-0434-5

Lourenço, A.P., Mackert, A., Cristino, A.D.S., Simões, Z.L.P. (2008) Validation of reference genes for gene expression studies in the honey bee, Apis mellifera, by quantitative real-time RT-PCR. Apidologie 39, 372385. https://doi.org/10.1051/apido:2008015

Lourenço, A.P., Santos, A.P.M., Checon, H.H. et al. (2020) Cavity-nesting bee communities in areas with different levels of vegetation disturbance. Stud Neotrop Fauna Environ 00, 1-13. https://doi.org/10.1080 /01650521.2019.1710334

Macivor, J.S. (2017) Cavity-nest boxes for solitary bees: a century of design and research. 48, 311-327. https://doi.org/10.1007/s13592-016-0477-z

Martins, G.F., Serrão, J.E. (2004) Changes in the reproductive tract of Melipona quadrifasciata anthidioides (Hymenoptera: Apidae, Meliponini) queen after mating. Sociobiology 44, 241-254

Martins, A.C., Melo, G.A.R., Renner, S.S. (2014) The corbiculate bees arose from New World oil-collecting bees: Implications for the origin of pollen baskets. Mol Phylogenet Evol 80, 88-94. https://doi.org/10.1016/j. ympev.2014.07.003

Michener, C.D. (2007) Bees of the world, 2nd edn. The Johns Hopkins University Press, Baltimore

Morandin, C., Hietala, A., Helanterä, H. (2019) Vitellogenin and vitellogenin-like gene expression patterns in relation to caste and task in the ant Formica fusca. Insectes Soc 66, 519-531. https://doi.org/10.1007 /s00040-019-00725-9

Moure, JS, Urban, D, Melo, GAR (2012) Catalogue of Bees (Hymenoptera, Apoidea) in the Neotropical Region - online version. http://www.moure.cria.org. br/catalogue. Accessed 18 Mar 2020

Münch, D., Ihle, K.E., Salmela, H., Amdam, G.V. (2015) Vitellogenin in the honey bee brain: Atypical localization of a reproductive protein that promotes longevity. Exp Gerontol 71, 103-108. https://doi.org/10.1016/j. exger.2015.08.001

Nelson, C.M., Ihle, K.E., Fondrk, M.K. et al. (2007) The gene vitellogenin has multiple coordinating effects on social organization. PLoS Biol 5, 0673-0677. https://doi.org/10.1371/journal.pbio.0050062
Pfaffl, M.W. (2001) A new mathematical model for relative quantification in real-time RT-PCR. Nucleic Acids Res 29, 45e-445e. https://doi.org/10.1093/nar/29.9.e45

Piulachs, M.D., Guidugli, K.R., Barchuk, A.R. et al. (2003) The vitellogenin of the honey bee, Apis mellifera: Structural analysis of the cDNA and expression studies. Insect Biochem Mol Biol 33 , 459-465. https://doi. org/10.1016/S0965-1748(03)00021-3

Raikhel, A., Dhadialla, T.S. (1992) Accumulation of yolk proteins in insect oocytes. Annu Rev Entomol 37, 217-251. https://doi.org/10.1146/annurev. ento.37.1.217

Richards, M.H. (2019) Vitellogenin and vitellogenin-like genes: not just for egg production. Insectes Soc 66, 505-506. https://doi.org/10.1007/s00040-019-00731$\mathrm{X}$

Romiguier, J., Cameron, S.A., Woodard, S.H. et al. (2016) Phylogenomics controlling for base compositional bias reveals a single origin of eusociality in corbiculate bees. Mol Biol Evol 33, 670-678. https://doi. org $/ 10.1093 / \mathrm{molbev} / \mathrm{msv} 258$

Rutherford, K., Parkhill, J., Crook, J. et al. (2000) Artemis: sequence visualization and annotation. Bioinformatics 16,944-945. https://doi.org/10.1093 /bioinformatics/16.10.944

Salmela, H., Amdam, G.V., Freitak, D. (2015) Transfer of immunity from mother to offspring is mediated via egg-yolk protein vitellogenin. PLoS Pathog 11, 112. https://doi.org/10.1371/journal.ppat.1005015

Santos, P.K.F., Arias, M.C., Kapheim, K.M. (2019) Loss of developmental diapause as a prerequisite for social evolution in bees. Biol Lett 15, 1-7. https://doi. org/10.1101/649897

Sappington, T.W., Raikhel, A. (1998) Molecular characteristics of insect vitellogenins and vitellogenin receptors. Insect Biochem Mol Biol 28, 277-300. https://doi. org/10.1016/S0965-1748(97)00110-0

Seehuus, S.C., Norberg, K., Gimsa, U. et al. (2006) Reproductive protein protects functionally sterile honey bee workers from oxidative stress. Proc Natl Acad Sci 103, 962-967. https://doi.org/10.1073/pnas.0502681103

Shen, Y., Chen, Y.Z., Lou, Y.H., Zhang, C.X. (2019) Vitellogenin and vitellogenin-like genes in the brown planthopper. Front Physiol 10, 1-15. https://doi. org/10.3389/fphys.2019.01181

Sumner, S., Bell, E., Taylor, D. (2018) A molecular concept of caste in insect societies. Curr Opin Insect Sci 25, 42-50. https://doi.org/10.1016/j.cois.2017.11.010

Tanaka, E.D., Hartfelder, K. (2004) The initial stages of oogenesis and their relation to differential fertility in the honey bee (Apis mellifera) castes. Arthropod Struct Dev 33, 431-442. https://doi.org/10.1016/j. asd.2004.06.006

Tanaka, É.D., Hartfelder, K. (2009) Sequence and expression pattern of the germ line marker vasa in honey bees and stingless bees. Genet Mol Biol 32, 582-593. https://doi.org/10.1590/S1415-47572009005000043

Tanaka, É.D., Schmidt Capella, I.C., Hartfelder, K. (2006) Cell death in the germline-mechanisms and 
consequences for reproductive plasticity in social bees. Braz J morphol Sci 23 , 15-26

Tian, H., Vinson, S.B., Coates, C.J. (2004) Differential gene expression between alate and dealate queens in the red imported fire ant, Solenopsis invicta Buren (Hymenoptera: Formicidae). Insect Biochem Mol Biol 34, 937-949. https://doi.org/10.1016/j. ibmb.2004.06.004

Tufail, M., Takeda, M. (2008) Molecular characteristics of insect vitellogenins. J Insect Physiol 54, 1447-1458. https://doi.org/10.1016/j.jinsphys.2008.08.007

Van Eeckhoven, J., Duncan, E.J. (2020) Mating status and the evolution of eusociality: Oogenesis is independent of mating status in the solitary bee Osmia bicornis . J Insect Physiol 121 , 104003. https://doi.org/10.1016/j. jinsphys.2019.104003
Wahli, W. (1988) Evolution and expression of vitellogenin genes. Trends Genet 4, 227-232. https://doi. org/10.1016/0168-9525(88)90155-2

Wheeler, D.E., Kawooya, J.K. (1990) Purification and characterization of honey bee vitellogenin. Arch Insect Biochem Physiol 14, 253-267. https://doi. org/10.1002/arch.940140405

Zhang, W., Liu, Z., Zhu, M. et al. (2017) Molecular cloning, expression and oxidative stress response of the vitellogenin Gene (AccVg) from Apis cerana cerana . Apidologie 48, 599-611. https://doi.org/10.1007 /s13592-017-0503-9

Publisher's note Springer Nature remains neutral with regard to jurisdictional claims in published maps and institutional affiliations. 